\title{
Suitability assessment of groundwater quality for irrigational use in Sagardighi block, Murshidabad district, West Bengal
}

\author{
Bhabani Prasad Mukhopadhyay ${ }^{1} \cdot$ Ananya Chakraborty $^{1} \cdot$ Amit Bera $^{1}$ (D) Ranajit Saha $^{2}$
}

Received: 20 July 2021 / Accepted: 22 December 2021 / Published online: 11 February 2022

(c) The Author(s) 2022

\begin{abstract}
Groundwater alone comprises nearly about $80 \%$ of the available water for irrigation purpose in Murshidabad and this usage of groundwater for irrigation is yet to increase further in the upcoming years. The present study was carried out to access the groundwater's suitability for different agricultural purposes in and around Sagardighi block of Murshidabad district, West Bengal, India. Groundwater samples from thirty three different locations around Sagardighi were collected and then tested in the laboratory for various physical as well as chemical parameters such as electrical conductivity (EC), total dissolved solids (TDS), $\mathrm{pH}$, some major cations $\left(\mathrm{Ca}^{2+}, \mathrm{Mg}^{2+}, \mathrm{Na}^{+}, \mathrm{K}^{+}, \mathrm{Fe}^{2+}\right)$ and some anions $\left(\mathrm{CO}_{3}{ }^{2-}, \mathrm{HCO}_{3}{ }^{-}, \mathrm{Cl}^{-}\right)$. To further delineate the suitable groundwater zones for irrigation practices, the irrigation water quality parameters such as sodium adsorption ratio (SAR), sodium percentage ( $\mathrm{Na} \%$ ), magnesium adsorption ratio (MAR), permeability index (PI), residual sodium carbonate (RSC), Kelly's ratio (KR) were also calculated. Results show that most of the water samples had low to medium salinity, while only a very few of the samples show high salinity. Piper trilinear plot reveals that the water is primarily of $\mathrm{Ca}-\mathrm{Mg}-$ $\mathrm{HCO}_{3}{ }^{-}$facies type. The SAR value of majority of the water samples in the study area are less than 10 , which is within safe limits. RSC values indicate that the carbonate content is extremely low in the groundwater of the study area. Overall, the results indicate that majority of the samples are fit to be used for irrigational purpose. The findings of this study would help decision-makers in developing irrigation suitability planning and groundwater resource management in the future.
\end{abstract}

Keywords Groundwater chemistry $\cdot$ Physico-chemical parameters $\cdot$ Hydrochemical facies $\cdot$ Irrigational water quality

\section{Introduction}

The availability of water largely impacts the overall economic and social development of an area. The ever increasing population growth together with technological advancement and evolving industrial society has resulted in a significant decline of this resource, especially groundwater, which in turn has led to some grave environmental problems (Bera et al. 2020). The groundwater in an area has a definite chemical composition and this change is dependent upon certain factors like rock-water interaction, temperature, mineral dissolution, soil-water interaction, the duration of

Amit Bera

amit.rs2017@geology.iiests.ac.in

1 Department of Earth Sciences, Indian Institute of Engineering Science and Technology, Shibpur, Howrah, West Bengal 711103, India

2 State Water Investigation Directorate (SWID), Government of West Bengal, Kolkata, India interaction and other anthropogenic activities (Subba Rao 2002; Bera and Das 2021). Nearly, 2.5 billion people depend solely upon the available groundwater for domestic and irrigation practices worldwide (UNESCO 2012; Grönwall and Danert 2020). For many decades, there has been some serious questions regarding the overall quality of the drinking water, available to us, from the health point of view. Owing to the insufficient surface water supply in most of the Indian locations, they solely depend upon groundwater to meet their daily needs.

Irrigation plays a very significant role in the production of crops as well as in the intensity of the crops produced. The main objective of using irrigation practices in agriculture is to increase the production of crops (Foster and Perry 2010). India is considered to be one of the prime countries worldwide, to extract the maximum amount $(89 \%)$ of groundwater for irrigational purposes, $9 \%$ for domestic needs and rest $2 \%$ for other industrial practices (Margat and Van Der Gun 2013). Therefore, an appropriate knowledge regarding the hydrochemistry of water is of 
utmost importance so as to properly evaluate the quality of the groundwater, especially in the rural areas as it significantly affects the usability of the groundwater for irrigation, domestic as well as for industrial needs (Biswas et al. 2020; Bera et al. 2021). Several studies (Rabeiy 2018; Aouiti et al. 2020; Aravinthasamy et al. 2021; Kadam et al. 2021; Kamaraj et al. 2021; Rao et al. 2021; Şener et al. 2021) have been conducted earlier regarding hydrochemistry and groundwater suitability for irrigation. The quality of the water used for irrigational purpose directly influences the yield of crops as well as land degradation. So, a proper groundwater quality assessment is extremely important for the management of agricultural water, proper food production and to understand its suitability for different needs (Bernstein 1975; Malash et al. 2000). According to the WHO (2011), availability of safe and clean drinking water is a universally recognized human right. The sustainability of crop yield and agri-food processing primarily depends upon the quality of the supplied water (Struik and Kuyper 2017; Aravinthasamy et al. 2021). To keep the soil structure stable, low sodic water is often preferred for irrigational purpose (Little et al. 2010). At present, GIS is commonly used as an effective tool to delineate the groundwater quality (Karunanidhi et al. 2013; Anand et al. 2019).

Murshidabad is fortunate to have abundant groundwater resources and a vast quantity of this water is utilized for domestic, irrigation and various other purposes. However, most of the groundwater available is only fairly suitable for irrigation purpose. A proper approach towards maintaining the overall balance between groundwater recharge and discharge and a continuous monitoring of the water samples for its proper management is mandatory in the study area to escape from the effect of long-term build-up of salinity. Works related to groundwater quality and its management in Murshidabad district have been previously performed by some researchers (Mukherjee et al. 2007; Farooq et al. 2010; Chowdhury and Paul 2019; Chatterjee et al. 2020; Mukhopadhyay et al. 2020). Since not much of extensive research has been carried out till date in and around Sagardighi to assess the water quality for irrigational practice, the primary objective of undertaking this work was to decide the suitability of the available groundwater for agricultural and irrigation practices in Sagardighi block of Murshidabad district, West Bengal. The chemical analyses of the samples will help us to compute various water quality indices, necessary for irrigation, such as percent sodium, sodium adsorption ratio (SAR), magnesium adsorption ratio (MAR), residual sodium carbonate (RSC), permeability index (PI) and Kelly's ratio (KR). This study can further assist in the development of a sustainable management of the groundwater for various agricultural practices for the local farmers as well as policy makers.

\section{Study area}

Sagardighi Block is located at the district of Murshidabad in West Bengal, which covers an area of about $345.2 \mathrm{~km}^{2}$ (Fig. 1). The area lies within the latitudes of $24^{\circ} 12^{\prime} 56^{\prime \prime}$ $\mathrm{N}$ and $24^{\circ} 24^{\prime} 25^{\prime \prime} \mathrm{N}$ and the longitudes of lies between $88^{\circ} 15^{\prime} 24^{\prime \prime} \mathrm{E}$ and $88^{\circ} 57^{\prime} 23^{\prime \prime} \mathrm{E}$. The district of Murshidabad roughly includes two distinct regions divided by the Bhagirathi River. The Rarh lies to the west and is an undulating continuation of the Chotanagpur plateau while the land around the Bhagirathi is called Bagri, a fertile part of the Ganga delta, a lush, low-lying alluvial tract. The study area belongs to humid tropical monsoonal type climate. The average annual rainfall in this region ranges from 1168 to $1500 \mathrm{~mm}$. In certain localities, double cropping is also found on a very local scale in areas where irrigation wells are found. In the present study, groundwater occurs primarily within a thick saturated zone of alluvium which is deposited by the rivers. The younger alluvium covers the entire study area and has a gently undulating slope, which generally trends southward. Most of the areas are agricultural lands. Agriculture is the main occupation for the majority of the population. During the dry seasons, the farmers are dependent on groundwater irrigation, canal irrigation and river lifting irrigation for farming. Paddy forms the staple food crop in this region. Apart from this, wheat, oilseeds, jute, corn, mustard, pulses and various horticulture crops (brinjal, cucurbits, cabbage, tomato, ladies finger, and cauliflower) are also grown. The soil in this area is mostly sandy and loamy soil along with younger alluvium (CGWB 2020). It has a high moisture content which is merely due to the water logged areas. The study area consists of light, rich alluvial soil. Bamboo, mango, sugarcane, berry constitute the popular trees found in the nearby villages. The deposition in this district took place by Ajoy-Damodar-Mayurakshi river system. Quaternary to recent alluvium sediments consisting of clay, silt, sand cover the study area. The size of the sand particles ranges from very fine to medium, yellow, grayish white, and are highly micaceous.

\section{Methodology}

To have a clear understanding about the hydrogeological condition of the study area, water samples from 33 shallow tubewells (35.67- $60.96 \mathrm{~m}$ deep) have been collected during the post-monsoon period (November, 2020) from various locations in Sagardighi block for a detailed physiochemical analysis. The water samples were collected in clean and sterilized $500 \mathrm{ml}$ sample bottles which were 

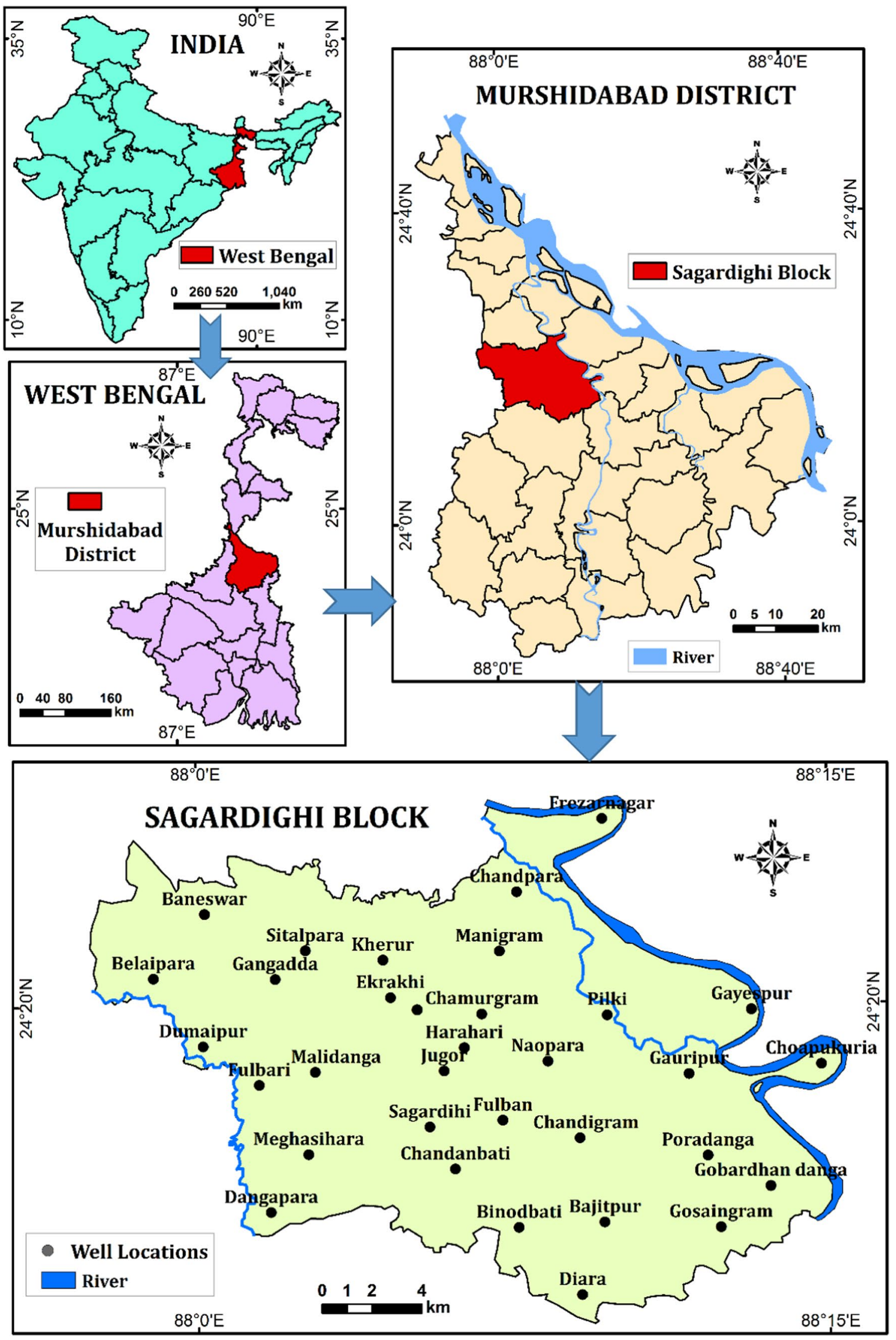

Fig. 1 Location of the study area 
rinsed properly with the same water that was being sampled. The tube wells were thoroughly pumped for about 8-10 min prior to collecting the water samples so that the water which is stored in the well-casing is lost and we directly get fresh groundwater samples from the aquifer below. After collection, the lid of the bottles were carefully sealed and they were all labelled accurately. The physical parameters of the water samples such as temperature, total dissolved solids (TDS), electrical conductivity (EC), and $\mathrm{pH}$ were all measured in the field itself by using Hanna Multi parameter waterproof meter (HI98194). The total alkalinity of the samples were calculated using the AQUASOL Alkalinity kit (AE-214) in the field. The samples were then filtered and carefully preserved with suitable regents and sent to the chemical laboratory for further geochemical analysis, within a week of their collection. The water samples were analysed in the laboratory for $\mathrm{Na}^{+}, \mathrm{K}^{+}, \mathrm{Mg}^{2+}, \mathrm{Ca}^{2+}, \mathrm{Fe}^{2+}, \mathrm{Cl}^{-}$and $\mathrm{HCO}_{3}{ }^{-}$(Table 1) using standard methods (APHA 1998). Cations like potassium $\left(\mathrm{K}^{+}\right)$and sodium $\left(\mathrm{Na}^{+}\right)$were measured by using Systonics 128, digital flame photometer. Magnesium $\left(\mathrm{Mg}^{2+}\right)$ and calcium $\left(\mathrm{Ca}^{2+}\right)$ were measured by EDTA (disodiumdihydrogen-ethylenediaminetetraacetate) titration method (Tucker and Kurtz 1961). The concentration of iron in the groundwater samples was measured by using colorimeter Move 100 with spectroquant reagents. Major anions such as sulphate $\left(\mathrm{SO}_{4}{ }^{2-}\right)$ were calculated using Aquasol sulphate testing kit. Chloride $\left(\mathrm{Cl}^{-}\right)$was measured by the Mohr method (4500 B-Cl-; argentometric method) (Mohr 1862). The suitability of the water for agricultural purpose

Table 1 Analytical data for the groundwater samples from the study area ( $\mathrm{EC}$ in $\mu \mathrm{S} / \mathrm{cm}$, remaining $\mathrm{mg} / \mathrm{l}$, except $\mathrm{pH}$ )

\begin{tabular}{|c|c|c|c|c|c|c|c|c|c|c|c|c|}
\hline Sample number & Location & $\mathrm{pH}$ & $\mathrm{EC}$ & $\mathrm{Ca}^{2+}$ & $\mathrm{Mg}^{2+}$ & $\mathrm{Na}^{+}$ & $\mathrm{K}^{+}$ & $\mathrm{Fe}^{+2 / 3}$ & $\mathrm{CO}_{3}{ }^{2-}+\mathrm{HCO}_{3}^{-}$ & $\mathrm{SO}_{4}^{2-}$ & $\mathrm{Cl}^{-}$ & Total hardness \\
\hline $\mathrm{L} 1$ & Binodbati & 8.4 & 412 & 36 & 9.72 & 23 & 1.6 & 16.3 & 130 & 9 & 28.4 & 129.89 \\
\hline L2 & Chandanbati & 8.3 & 295 & 28 & 21.87 & 25 & 0.4 & 0.37 & 180 & 5 & 14.2 & 159.91 \\
\hline L3 & Sagardighi & 8.5 & 489 & 96 & 24.3 & 43 & 3.3 & 5.96 & 160 & 10 & 163.1 & 339.71 \\
\hline L4 & Karaiya & 8.5 & 238 & 52 & 26.7 & 30 & 8 & 1.28 & 260 & 12 & 21.3 & 239.71 \\
\hline L5 & Ekrakhi & 8.1 & 362 & 64 & 19.4 & 35 & 1.3 & 3.68 & 280 & 8 & 28.4 & 239.64 \\
\hline L6 & Naopara & 8.4 & 294 & 84 & 19.3 & 23 & 0.2 & 0.86 & 270 & 12 & 63.8 & 289.17 \\
\hline L7 & Chamurgram & 8.3 & 351 & 72 & 19.4 & 26 & 0.4 & 0.19 & 360 & 9 & 28.4 & 259.62 \\
\hline L8 & Manigram & 8.4 & 338 & 116 & 36.5 & 25 & 3.1 & 2.32 & 370 & 12 & 142.5 & 439.85 \\
\hline L9 & Sitalpara & 8.2 & 273 & 60 & 19.4 & 24 & 4.3 & 1.1 & 290 & 5 & 21.3 & 229.65 \\
\hline L10 & Gangadda & 8.5 & 267 & 48 & 7.3 & 23 & 3.1 & 0.08 & 180 & 4 & 21.3 & 149.90 \\
\hline L11 & Meghasihara & 8.4 & 261 & 52 & 17.01 & 30 & 3.3 & 6.4 & 230 & 7 & 28.4 & 199.84 \\
\hline L12 & Jugor & 8.3 & 168 & 56 & 26.7 & 49 & 3.2 & 2.92 & 270 & 5 & 21.3 & 249.70 \\
\hline L13 & Harahari & 8.1 & 251 & 64 & 19.4 & 47 & 3.1 & 0.5 & 280 & 7 & 28.4 & 239.64 \\
\hline L14 & Kherur & 8.3 & 401 & 72 & 14.6 & 38 & 0.8 & 0.06 & 310 & 6 & 21.3 & 239.86 \\
\hline L15 & Bajitpur & 7.2 & 351 & 48 & 12.2 & 52 & 3 & 6.84 & 190 & 0 & 14.2 & 170.06 \\
\hline L16 & Pilki & 8 & 385 & 72 & 26.7 & 46 & 0.7 & 2.06 & 370 & 10 & 28.4 & 289.65 \\
\hline L17 & Gobardhan danga & 8.4 & 178 & 80 & 26.7 & 50 & 0.5 & 3.3 & 320 & 14 & 49.6 & 309.63 \\
\hline L18 & Chandigram & 8.5 & 391 & 52 & 17.01 & 65 & 2 & 1.49 & 210 & 12 & 35.5 & 199.84 \\
\hline L19 & Gosaingram & 8.1 & 569 & 10 & 3.6 & 4.9 & 2.1 & 1.44 & 220 & 18 & 53 & 39.78 \\
\hline L20 & Diara & 8.4 & 197 & 64 & 21.2 & 19 & 1.3 & 14.3 & 300 & 0 & 14.2 & 247.05 \\
\hline L21 & Fulban & 7.6 & 487 & 48 & 18.3 & 23 & 3.1 & 3.55 & 171 & 14 & 64.3 & 195.16 \\
\hline L22 & Gauripur & 7.7 & 574 & 60 & 24.1 & 8 & 0.8 & 0.25 & 153 & 16 & 107.2 & 248.99 \\
\hline L23 & Gayespur & 8 & 557 & 50 & 17.3 & 21 & 4.3 & 4.09 & 201 & 14 & 53.3 & 196.04 \\
\hline L24 & Choapukuria & 7.9 & 616 & 98 & 15.1 & 12 & 2.6 & 0.68 & 299 & 10 & 60.2 & 306.84 \\
\hline L25 & Chandpara & 8.4 & 614 & 80 & 19.4 & 19 & 1.3 & 1.53 & 320 & 10 & 21.3 & 279.59 \\
\hline L26 & Frezarnagar & 8.5 & 307 & 56 & 14.58 & 27 & 1.6 & 0.72 & 260 & 6 & 21.3 & 199.83 \\
\hline L27 & Belaipara & 7.9 & 555 & 44 & 24.5 & 26 & 0.4 & 5.36 & 281 & 0 & 7.1 & 210.69 \\
\hline L28 & Malidanga & 7.5 & 598 & 32 & 12.5 & 47 & 3.1 & 2 & 195 & 17 & 89.2 & 131.34 \\
\hline L29 & Baneswar & 6.8 & 493 & 30 & 17 & 28 & 3 & 0.37 & 171 & 14 & 43.5 & 144.87 \\
\hline L30 & Dumaipur & 7.9 & 604 & 54 & 9.7 & 69 & 8.9 & 1.24 & 293 & 7 & 18.3 & 174.75 \\
\hline L31 & Dangapara & 7.9 & 653 & 50 & 29.03 & 25 & 0.6 & 1.7 & 336 & 13 & 32.6 & 244.31 \\
\hline L32 & Poradanga & 6.9 & 447 & 52 & 16.2 & 25 & 3.1 & 1.08 & 195 & 9 & 64.8 & 196.51 \\
\hline L33 & Fulbari & 7.5 & 701 & 52 & 24.1 & 56 & 3 & 2.96 & 256 & 14 & 89.2 & 229.02 \\
\hline
\end{tabular}


Table 2 Irrigation water quality evaluation for the groundwater of the study area

\begin{tabular}{|c|c|c|c|c|c|c|c|}
\hline Sample number & Location & SAR & $\mathrm{Na} \%$ & MAR & $\mathrm{KR}$ & PI & RSC \\
\hline L1 & Binodbati & 4.81 & 34.98 & 21.26 & 0.503 & 50.06 & -0.48 \\
\hline L2 & Chandanbati & 5 & 33.74 & 43.85 & 0.501 & 51.31 & -0.27 \\
\hline L3 & Sagardighi & 5.54 & 27.79 & 20.19 & 0.357 & 34.08 & -4.20 \\
\hline L4 & Karaiya & 4.78 & 32.56 & 33.93 & 0.381 & 42.43 & -0.56 \\
\hline L5 & Ekrakhi & 5.42 & 30.32 & 23.26 & 0.419 & 43.69 & -0.23 \\
\hline L6 & Naopara & 3.2 & 18.33 & 18.68 & 0.222 & 31.22 & -1.38 \\
\hline L7 & Chamurgram & 3.85 & 22.41 & 21.22 & 0.284 & 38.3 & 0.69 \\
\hline L8 & Manigram & 2.86 & 15.55 & 23.93 & 0.164 & 24.92 & -2.78 \\
\hline L9 & Sitalpara & 3.81 & 26.27 & 24.43 & 0.302 & 39.68 & 0.14 \\
\hline L10 & Gangadda & 4.37 & 32.06 & 13.2 & 0.416 & 46.5 & -0.06 \\
\hline L11 & Meghasihara & 5.11 & 32.55 & 24.64 & 0.435 & 45.62 & -0.25 \\
\hline L12 & Jugor & 7.62 & 38.69 & 32.28 & 0.592 & 49.68 & -0.60 \\
\hline L13 & Harahari & 7.28 & 37.52 & 23.26 & 0.563 & 48.87 & -0.23 \\
\hline L14 & Kherur & 5.77 & 30.94 & 16.86 & 0.438 & 44.63 & 0.27 \\
\hline L15 & Bajitpur & 9.48 & 47.74 & 20.26 & 0.863 & 58.63 & -0.30 \\
\hline L16 & Pilki & 6.55 & 32.11 & 27.05 & 0.466 & 45.08 & 0.24 \\
\hline L17 & Gobardhan danga & 6.84 & 32.12 & 25.02 & 0.468 & 43.32 & -0.98 \\
\hline L18 & Chandigram & 11.06 & 49.26 & 24.65 & 0.942 & 59.31 & -0.58 \\
\hline L19 & Gosaingram & 1.88 & 33.98 & 26.47 & 0.36 & 106.66 & 2.81 \\
\hline L20 & Diara & 2.91 & 19.24 & 24.88 & 0.223 & 34.85 & -0.05 \\
\hline L21 & Fulban & 3.99 & 28.24 & 27.6 & 0.347 & 40.39 & -1.12 \\
\hline L22 & Gauripur & 1.23 & 9.47 & 28.66 & 0.095 & 22.11 & -2.50 \\
\hline L23 & Gayespur & 3.62 & 27.32 & 25.7 & 0.312 & 39.83 & -0.65 \\
\hline L24 & Choapukuria & 1.59 & 11.43 & 13.35 & 0.106 & 23.41 & -1.26 \\
\hline L25 & Chandpara & 2.69 & 16.96 & 19.52 & 0.191 & 31.15 & -0.37 \\
\hline L26 & Frezarnagar & 4.54 & 28.83 & 20.66 & 0.382 & 44.19 & 0.25 \\
\hline L27 & Belaipara & 4.44 & 27.81 & 35.77 & 0.379 & 45.25 & 0.36 \\
\hline L28 & Malidanga & 9.96 & 52.96 & 28.09 & 1.056 & 66.63 & 0.58 \\
\hline L29 & Baneswar & 5.77 & 39.74 & 36.17 & 0.595 & 54.76 & -0.11 \\
\hline L30 & Dumaipur & 12.22 & 55.01 & 15.22 & 1.083 & 64.89 & 1.30 \\
\hline L31 & Dangapara & 3.97 & 24.46 & 36.73 & 0.316 & 41.65 & 0.59 \\
\hline L32 & Poradanga & 4.28 & 29.17 & 23.75 & 0.366 & 41.8 & -0.75 \\
\hline L33 & Fulbari & 9.07 & 43.67 & 31.67 & 0.736 & 54.5 & -0.41 \\
\hline
\end{tabular}

was evaluated by using certain irrigational quality parameters (Table 2). Piper's trilinear plot is done to find the geochemical facies to which the groundwater samples belong. USSL Diagram has been done to classify the water samples based upon their sodium hazard (SAR) and salinity hazard (EC) values. SAR provides important information based upon the comparative concentrations of $\mathrm{Ca}^{2+}, \mathrm{Na}^{+}$ and $\mathrm{Mg}^{2+}$ in the soil solution. The SAR is calculated by the formula given by Richards (1954) as follows:

$\mathrm{SAR}=\frac{\mathrm{Na}^{+}}{\frac{1}{2} \sqrt{\mathrm{Ca}^{2+}+\mathrm{Mg}^{2+}}}$

Kelly's ratio is measured in ratio, by the $\mathrm{Na}^{+}$concentration in water against the total concentration of $\mathrm{Mg}^{+2}$ and $\mathrm{Ca}^{+2}$ (Kelley 1940). Kelly's ratio is calculated as:
$\mathrm{KR}=\frac{\mathrm{Na}^{+}}{\mathrm{Ca}^{2+}+\mathrm{Mg}^{2+}}$

A Kelly's ratio $>1$ indicates high sodium concentration in water and are therefore unsuitable for irrigation while those having a $\mathrm{KR}<1$ are suitable.

Another critical parameter to consider when determining the suitability of water for irrigation is the sodium percentage. Sodium percentage is calculated as:

$\mathrm{Na} \%=\frac{(\mathrm{Na}+\mathrm{K}) \times 100}{(\mathrm{Ca}+\mathrm{Mg}+\mathrm{Na}+\mathrm{K})}$

MAR is calculated as: 
$\operatorname{MAR}=\frac{M g}{(M g+C a)} \times 100$

Permeability index (PI) is calculated using the formulae:

$\mathrm{PI}=\frac{\mathrm{Na}+\sqrt{\mathrm{HCO}_{3}}}{\mathrm{Ca}+\mathrm{Mg}+\mathrm{Na}} \times 100$

Charge balance of all the samples ranged within a permissible limit of $\pm 10 \%$, indicating that the analysed results are reliable. The error in the results calculated might be due to some limitation of the various procedures or the reagents used. The value of the various cations and anions in the samples along with the different physical parameters is shown in Table-1. Based upon the calculated values, the samples were grouped according to the international standards. The spatial distribution was carried out for selected physicochemical parameters and irrigation water quality parameters of groundwater samples for postmonsoon period using inverse distance weighted (IDW) interpolation technique in ArcGIS 10.0 environment. The classification of irrigational groundwater parameters is given in Table 3.

Pearson correlation of 10 parameters and samples $(n=33)$ was calculated using SPSS 16.0 software. Hierarchical cluster analysis (HCA) is a significant form of multivariate analysis that has been used to sort different groundwater samples into groups or clusters based on their similarities (Helena et al. 2000). Principal component analysis (PCA) is also a useful method to assess the interrelationship among the hydrochemical variables by reducing the number of variables (Chakraborty et al. 2021). Initially, Ward's clustering method, followed by extraction method with Eigen value set to 1 based on Kaiser criterion, and finally the Varimax method selected as the rotation factor were followed. SPSS 16.0 software was used to perform both HCA and PCA analyses.
Table 3 Classification of irrigational groundwater parameters

\begin{tabular}{|c|c|c|c|}
\hline Parameters & References & Range & Suitability classification \\
\hline $\mathrm{EC}(\mu \mathrm{S} / \mathrm{cm})$ & $\begin{array}{l}\text { Richards (1954), } \\
\text { Wilcox (1955), } \\
\text { Romanelli et al. (2012) }\end{array}$ & $\begin{array}{l}<250 \\
250-500 \\
500-750\end{array}$ & $\begin{array}{l}\text { Excellent } \\
\text { Good } \\
\text { Doubtful }\end{array}$ \\
\hline $\mathrm{Cl}(\mathrm{mg} / \mathrm{l})$ & $\begin{array}{l}\text { Ayers and Westcot (1985), } \\
\text { Simsek and Gunduz (2007) }\end{array}$ & $\begin{array}{l}<140 \\
140-350\end{array}$ & $\begin{array}{l}\text { Highly suitable } \\
\text { Suitable }\end{array}$ \\
\hline $\mathrm{pH}$ & $\begin{array}{l}\text { Ayers and Westcot (1985), } \\
\text { Simsek and Gunduz (2007 }\end{array}$ & $\begin{array}{l}7-8 \\
6.5-7\end{array}$ & $\begin{array}{l}\text { Excellent } \\
\text { Good }\end{array}$ \\
\hline $\mathrm{TH}(\mathrm{mg} / \mathrm{l})$ & Sawyer and McCarty (1967) & $\begin{array}{l}75-150 \\
150-300 \\
>300\end{array}$ & $\begin{array}{l}\text { Moderate } \\
\text { Hard } \\
\text { Very hard }\end{array}$ \\
\hline SAR & Ayers and Westcot (1985) & $\begin{array}{l}<3 \\
3-9 \\
>9\end{array}$ & $\begin{array}{l}\text { Excellent } \\
\text { Good } \\
\text { Permissible }\end{array}$ \\
\hline $\mathrm{Na} \%$ & $\begin{array}{l}\text { Wilcox (1955), } \\
\text { Islam et al. (2018) }\end{array}$ & $\begin{array}{l}<20 \\
20-40 \\
40-60\end{array}$ & $\begin{array}{l}\text { Excellent } \\
\text { Good } \\
\text { Permissible }\end{array}$ \\
\hline MAR & Szabolcs and Darab (1964) & $\begin{array}{l}<50 \\
>50\end{array}$ & $\begin{array}{l}\text { Suitable } \\
\text { Unsuitable }\end{array}$ \\
\hline RSC & Eaton (1950) & $\begin{array}{l}<1.25 \\
1.25-2.5 \\
>2.5\end{array}$ & $\begin{array}{l}\text { Good } \\
\text { Doubtful } \\
\text { Unsuitable }\end{array}$ \\
\hline KR & Kelley (1940) & $\begin{array}{l}<1 \\
>1\end{array}$ & $\begin{array}{l}\text { Suitable } \\
\text { Unsuitable }\end{array}$ \\
\hline PI & Doneen (1964) & $\begin{array}{l}>75(\text { Class I) } \\
75-25(\text { Class II }) \\
<25 \text { (Class III) }\end{array}$ & $\begin{array}{l}\text { Perfectly suitable } \\
\text { Moderately suitable } \\
\text { Unsuitable }\end{array}$ \\
\hline
\end{tabular}




\section{Results and discussion}

\section{Groundwater quality based on the physicochemical parameters}

Water quality is primarily determined by the type of water and the amount of ions and elements dissolved in it. Table-1 shows the basic physicochemical parameters for each sample site. $\mathrm{pH}$ is measured to determine the alkaline or acidic nature of the groundwater samples. $\mathrm{pH}$ and alkalinity are the two of the principal parameters which significantly manipulates the suitability of the groundwater for irrigation practice. The usual $\mathrm{pH}$ values for irrigation water vary from 6.5 to 8.4 (Bauder et al. 2011). Generally $\mathrm{pH}<7$ indicates acidic solution, $\mathrm{pH}=7$ is neutral and $\mathrm{pH}>7$ is alkaline. In the present study, the $\mathrm{pH}$ ranges from 6.8 to 8.5 , suggesting that the water is mostly alkaline in nature and perfectly suitable for irrigation. Electrical conductivity (EC) is directly proportional to the number of various conductive ions which are present in the water samples. Calcium $\left(\mathrm{Ca}^{+2}\right)$ and magnesium $\left(\mathrm{Mg}^{+2}\right)$ are the two most dominant cations present in groundwater. In this region, the concentration of calcium $\mathrm{Ca}^{+2}$ varies from $10-116 \mathrm{mg} / \mathrm{l}$ and that of $\mathrm{Mg}^{+2}$ ranges from 3.6 to $36.5 \mathrm{mg} / \mathrm{l}$. Potassium (K) ranges from $0.2 \mathrm{mg} / \mathrm{l}$ at Naopara to $8.9 \mathrm{mg} / \mathrm{l}$ at Dumaipur. The value of sodium $\left(\mathrm{Na}^{+}\right)$ranges from $4.9 \mathrm{mg} / \mathrm{l}$ in Gosaingram to $69 \mathrm{mg} / \mathrm{l}$ at Dumaipur. Iron is also an essential component to maintain the hardness of the water. The permissible limit for iron within water is $0.3 \mathrm{mg} / \mathrm{l}$ (BIS 2021). The iron content of the study area varies between 0.06 and $16.3 \mathrm{mg} / \mathrm{l}$ indicating that groundwater from a few localities are rich in iron. Chloride $\left(\mathrm{Cl}^{-}\right)$ naturally occurs in groundwater and it is one of the most significant of all the parameters analysed in the groundwater samples. The $\mathrm{Cl}^{-}$concentration in the study area varies from 7.1 to $163.1 \mathrm{mg} / \mathrm{l}$ which is safe and lies within the desirable limit of $<200 \mathrm{mg} / \mathrm{l}$. The concentration of carbonate and bicarbonate was higher at Manigram $(370 \mathrm{mg} / \mathrm{l})$ and lower at Binodbati $(130 \mathrm{mg} / \mathrm{l})$. Total hardness (TH) of the water samples ranges from $39.78 \mathrm{mg} / \mathrm{l}$ at Gosaingram to a maximum value of $439.85 \mathrm{mg} / \mathrm{l}$ at Manigram with an average value of $224.85 \mathrm{mg} / \mathrm{l}$. According to WHO (2011), the maximum permissible limit of TDS is $500 \mathrm{mg} / \mathrm{l}$ and $100 \mathrm{mg} / \mathrm{l}$ is the desirable limit. In the study area, all of the samples have values ranging within allowable limits and hence is primarily soft water.
Fig. 2 Piper diagram representing hydrochemical facies of groundwater of the study area

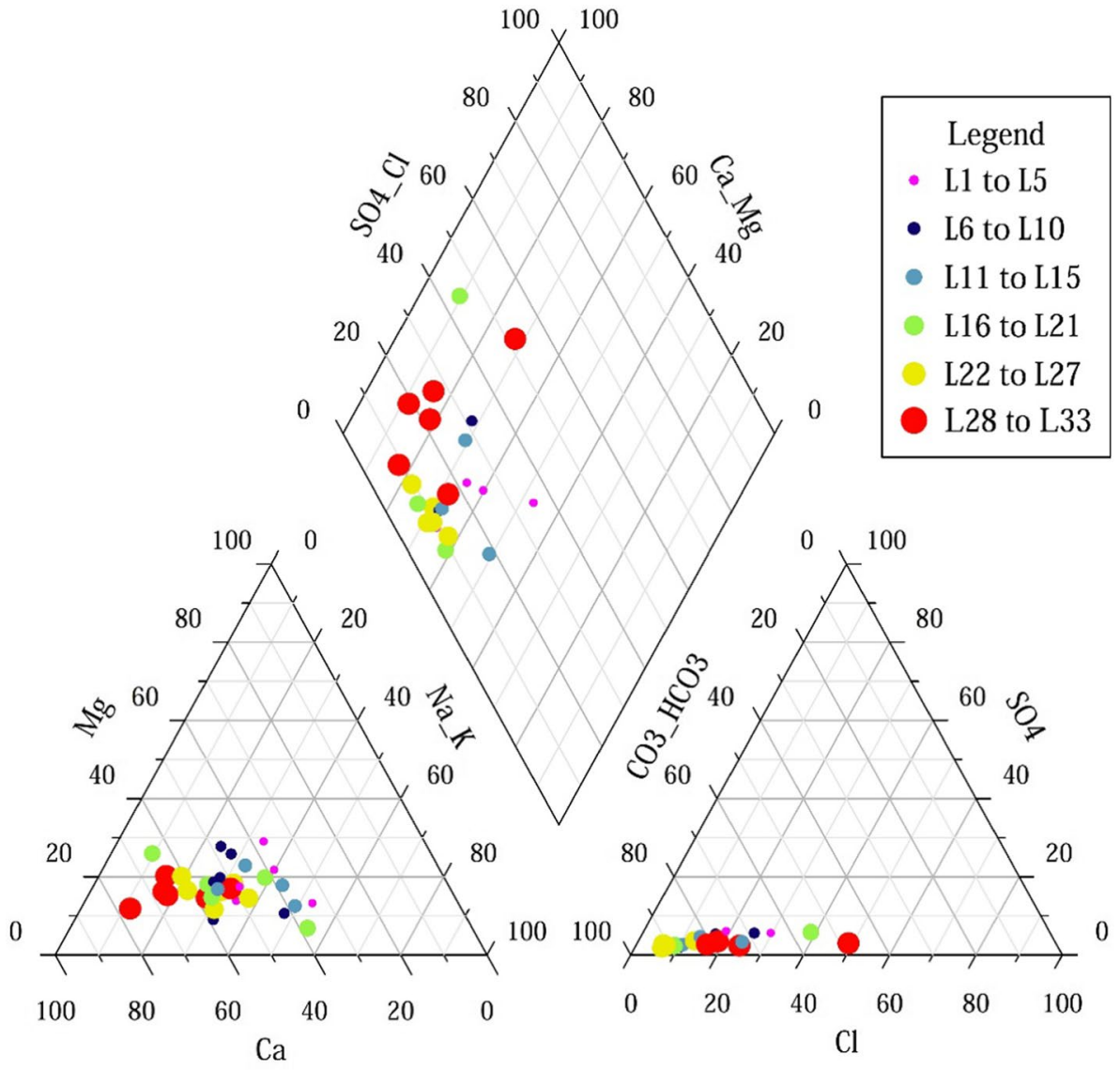




\section{Hydrochemical facies}

The Piper plot was done depending upon the concentration of the major cations and anions as found in the water samples. The (Piper's 1944) plot helps in identifying the various hydrochemical facies type present within a given groundwater basin. The samples contain the cations and anions in decreasing order of dominance as $\mathrm{Ca}^{+2}>\mathrm{Mg}^{+2}>\mathrm{Na}^{+}>\mathrm{K}^{+}>\mathrm{Fe}^{+2}$ and $\mathrm{HCO}_{3}{ }^{-}>\mathrm{Cl}^{-}>\mathrm{SO}_{4}{ }^{-}>\mathrm{CO}_{3}{ }^{2-}$, respectively. From Fig. 2, it can be seen that most of the groundwater samples are concentrated inside field 5, indicating that the water is of $\mathrm{Ca}-\mathrm{Mg}-\mathrm{HCO}_{3}{ }^{-}$(calcium magnesium bicarbonate) facies type and is absolutely suitable for irrigation (Kundu and Nag 2018). The overall concentration of the major cations and anions of the samples in the study area is shown in Table 1.

Durov's (1948) diagram is a combined plot which comprises of two separate ternary diagrams where the major cations of interest are plotted against the anions and both are expressed in milli equivalent percentages (Fig. 3). It is an extended version of the Piper plot where the $\mathrm{pH}$ data are also plotted against the TDS (total dissolved solids in $\mathrm{mg} / \mathrm{l}$ ) on both sides of the main binary plot so as to permit further observations (Verma et al. 2020). From the plot, it can be seen that most of the samples fall in field 5 of the plot indicating no such dominant anion or cation while a few fall in field 1 of the plot suggesting that $\mathrm{Ca}^{2+}$ and $\mathrm{HCO}_{3}{ }^{-}$forms the dominant cation and anion in those samples respectively.

\section{Irrigational water quality}

\section{Salinity hazard}

Water salinity is commonly calculated by measuring the electrical conductivity (EC). This value helps us to determine the salinity hazards which further enables us to rate the overall quality of the irrigation water. Groundwater having high conductivity values and therefore excessive salinity causes a salinity hazard to the crop and plants (Fipps 2003; Subramani et al. 2005). Continued usage of groundwater with very high EC values directly affects the yield of the crops (Kumar et al. 2017). Higher concentration of sodium and EC in water used for irrigation purposes decreases the soil's osmotic pressure and therefore reduces the overall consumption of various nutrients by the plants leading to poor growth (Saleh et al. 1999; Keesari et al. 2016). High sodium percentage in groundwater sample also leads to a low permeability of the soil and overall soil dryness (Subramani et al. 2005). In the study area, the $\mathrm{EC}$ value at $25^{\circ} \mathrm{C}$ ranges from 168 to $701 \mu \mathrm{S} / \mathrm{cm}$ (Fig. 4a), which is much within the permissible limit suggesting that there is no salinity hazard in the area.

\section{Sodium adsorption ratio (SAR)}

According to the WHO (1989), irrigation water is mostly graded based upon the SAR value. Therefore, when
Fig. 3 Expanded Durov diagram for depicting evolution of hydrochemical facies in the study area

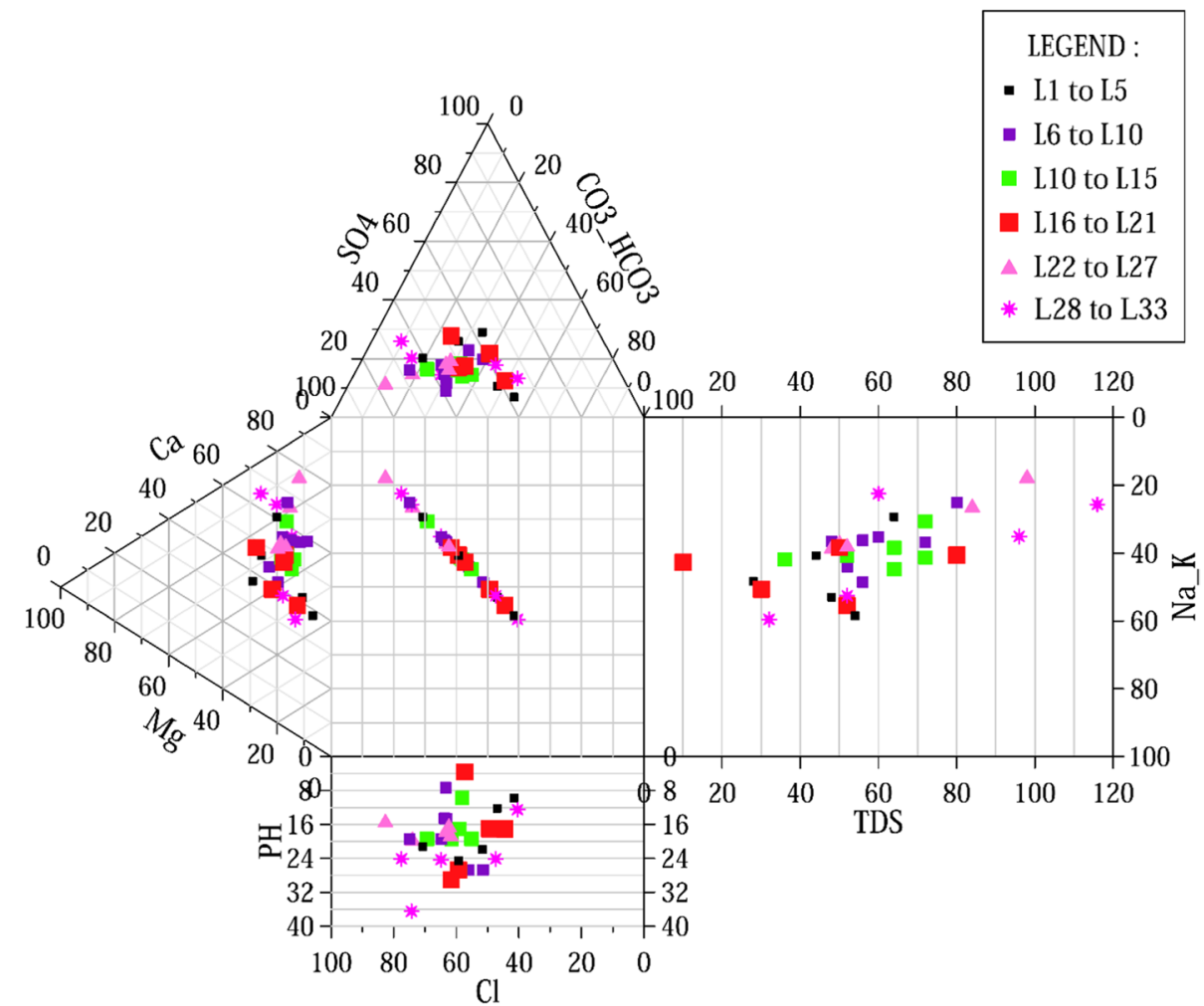



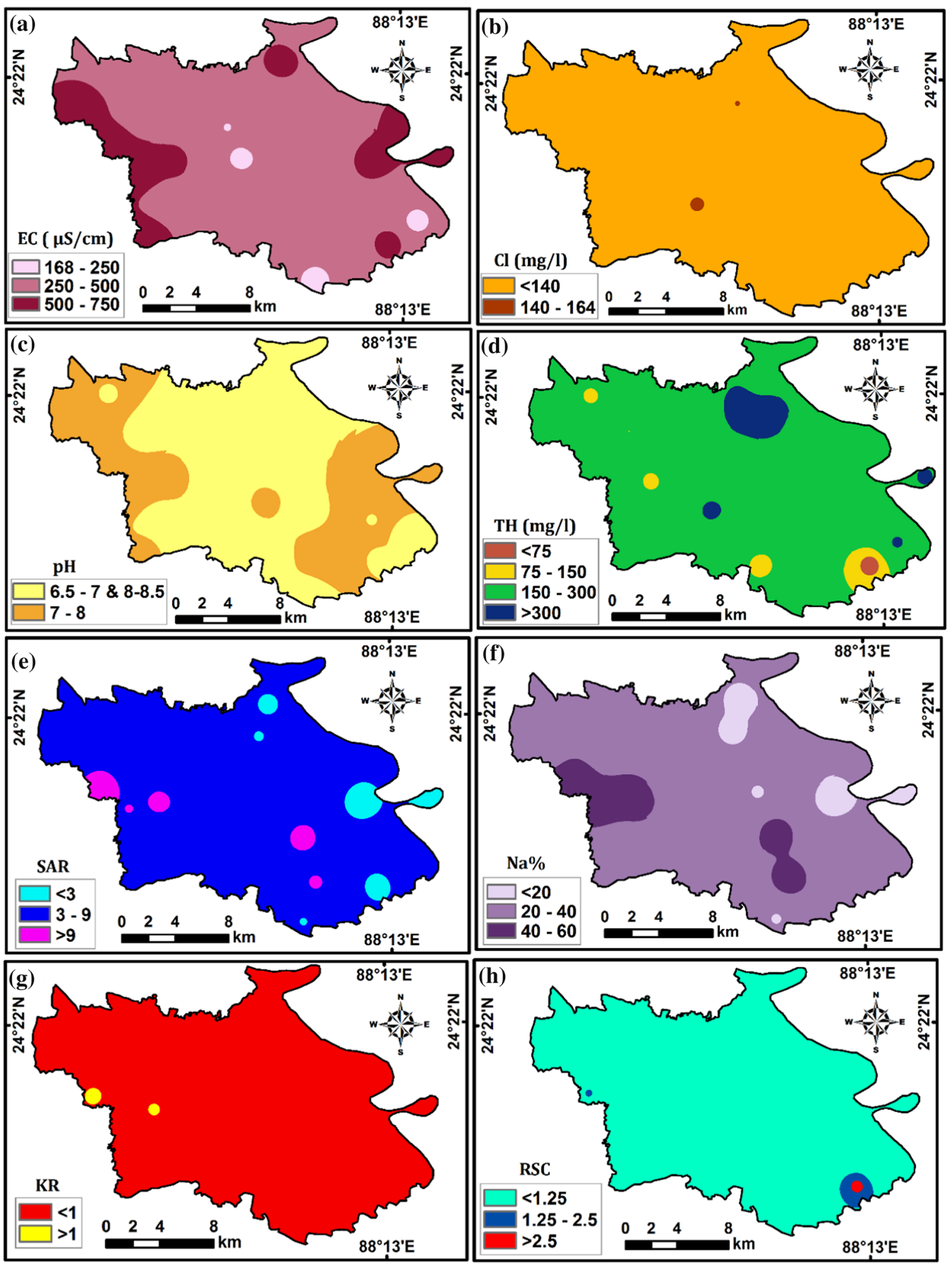

Fig. 4 Spatial distribution maps of irrigation water quality evaluation indices in the study area; a EC; b Cl; $\mathbf{c}$ pH; $\mathbf{d}$ TH; e SAR; $\mathbf{f ~ N a \% ; ~} \mathbf{g} \mathrm{KR}$; h RSC

deciding the suitability of water for irrigation purpose, evaluating the sodium hazard is absolutely necessary. SAR is one of the most critical criteria while determining the sodium hazard (Adimalla 2020). In the study area, the overall SAR value ranging from 1.23 to 12.22 (Fig. 4e), with an average value of 5.32. In the study area, about 
$73 \%$ water samples are within safe limits $(<6)$, whereas $6 \%$ of the water samples are unfit (SAR $>10)$ and $21 \%$ are just marginally fit (SAR 6-10) for irrigation. However, in Sagardighi, the SAR value of majority of the samples are less than 10 and are therefore excellent for irrigation purpose (Richards 1954). SAR further determines the relative movement of the $\mathrm{Na}^{+}$ions within the exchange reactions of soil. This ratio further develops the relative concentration of sodium ions to magnesium and calcium (Wang 2013). When groundwater having high SAR value is added to a soil, the $\mathrm{Na}^{+}$ions present in the water can immediately dislocate the $\mathrm{Mg}^{+2}$ and $\mathrm{Ca}^{+2}$ ions present in the soil. This will create a hindrance in creating a stable soil aggregate and therefore cause much damage to the soil structure. This can further reduce the infiltration rate or the permeability of water into the soil with a significant decrease in the overall crop yield (Nouri et al. 2017). High amount of sodium in the soil often results in clogging of the pores in soil, by some organic matter or soil clays which then reduces the soil aeration and water infiltration rate. In addition to these, the soil also becomes compact and very hard upon drying (Rhoades 1987). Therefore, if sodium water is the only supply of irrigation water, it is always advisable to avoid using such water having high sodium value, as the continued use of such water will ultimately lead to a deterioration of the soil's overall physical structure (Hadas 1982). These problems are much more experienced in case of finely textured soils like loam and clays.

\section{USSL diagram}

The US salinity diagram (USSL) relates the SAR and EC values of water and is used to determine the irrigation water suitability (Richards 1954; Sundaray et al. 2009). The plot implies that majority of the water samples lie in the C2S1 zone which suggests good to permissible category, while a few lies in the C1S1 and C2S2 zone which is the excellent to good and permissible to doubtful category, respectively (Fig. 5). Therefore, majority of the groundwater samples in the study area has a low sodium hazard and moderate salinity hazard and are appropriate for agricultural purpose. From the plot, it is evident that the water is appropriate for irrigational purpose, provided there is moderate leaching and the crops are resistant to moderate salinity.

\section{Kelly's ratio (KR)}

In the study area, KR ranges from 0.095 to 1.083 with an average value of 1.15 . Moderately high KR ratio (0.736-0.942) can be observed in Fulbari, Bajitpur, Chandigram regions. Gauripur, Choapukuria, Manigram, Chandpara areas have low KR ratio $(<0.2)$. Around $93.94 \%$ of the samples have a KR $<1$ and are suitable for irrigation, whereas $6.06 \%$ of the total sample (Malidanga and Dumaipur) has KR greater than 1, indicating their unsuitability for irrigation. Majority of the water can be used in agriculture.
Fig. 5 USSL Diagram showing classification based on sodium hazard (SAR) and salinity hazard (EC)

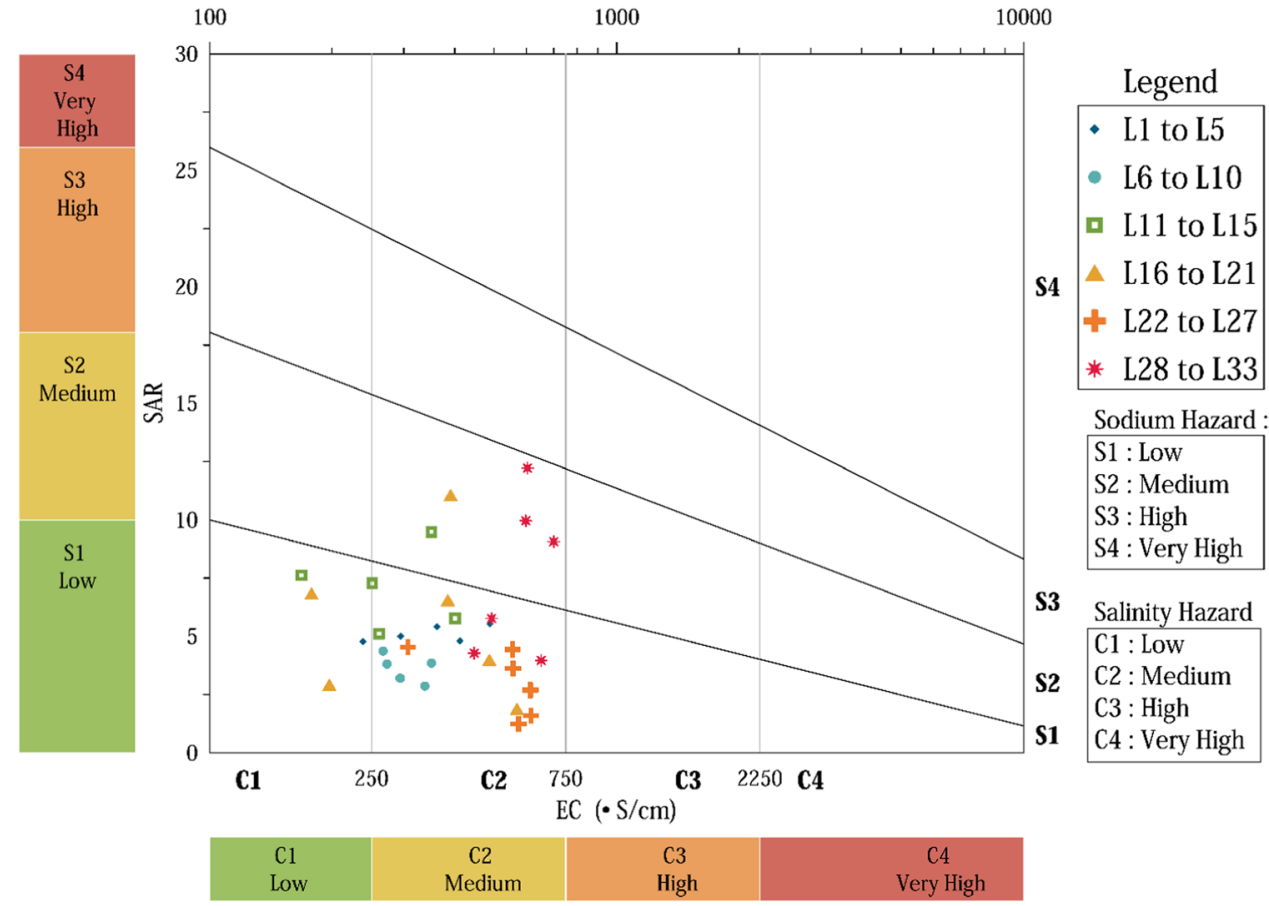




\section{Sodium percentage ( $\mathrm{Na} \%)$}

When there is an excess of sodium in water, it can combine with carbonates, resulting in alkaline soils, and excess sodium combined with chlorides results in saline soils, reducing soil permeability. The percent sodium $(\mathrm{Na} \%)$ values in the study area range from $9.47 \%$ to $55.01 \%$ (Fig. 4f), with an average value of $31 \%$. In Wilcox diagram, EC of the groundwater samples is plotted against $\mathrm{Na} \%$ on a semi-log plot in accordance with the US Salinity Laboratory scheme, to determine the usability of water for irrigation purpose (Wilcox 1955). As per Wilcox's plot, irrigation water can be grouped into five different classes such as: excellent to good, good to permissible, permissible to doubtful, doubtful to unsuitable and unsuitable. The result showed that $93 \%$ of the groundwater samples (from 31 locations) fall within the excellent category, while only $7 \%$ (2 locations) have values which fall in the good category (Fig. 6). Only $3 \%$ of the data falls in the permissible to doubtful class.

\section{Residual sodium carbonate (RSC)}

Residual sodium carbonate is a relative measure of the carbonate $\left(\mathrm{CO}_{3}{ }^{2-}\right)$ and bicarbonate $\left(\mathrm{HCO}_{3}{ }^{-}\right)$ions as compared to $\mathrm{Ca}^{2+}$ and $\mathrm{Mg}^{2+}$ found in the water samples. The problem of RSC arises in irrigation water only when the $\mathrm{HCO}_{3}{ }^{-}$plus carbonate $\mathrm{CO}_{3}{ }^{2-}$ content surpasses the total $\mathrm{Mg}^{2+}$ plus $\mathrm{Ca}^{2+}$ content of the groundwater, which isn't the case here (Naseem et al. 2010). Long-term usage of water having very high RSC for agricultural practices will cause an unwanted accumulation of excessive $\mathrm{Na}^{+}$in soil. The RSC values in the study area range from -4.2 to 2.8 (Fig. 4h), with an average value of -0.75 . Majority of the RSC values are negative which indicates that the amount of $\mathrm{Mg}^{2+}$ and $\mathrm{Ca}^{2+}$ ions present in the groundwater is much greater than that of the carbonates (Asante-Annor et al. 2018).

\section{Magnesium adsorption ratio (MAR)}

Magnesium is regarded as a necessary nutrient for plant growth. Lower magnesium levels can cause plant growth to slow, affecting crop yield in the long run. As a result, the magnesium content in water is likely to influence the suitability of water for irrigation. A value of MAR $>50$ is unsuitable for agriculture as it adversely affects the crop yield and quality. In Sagardighi, the overall value of MAR ranges from 13.20 in Gangadda to 43.85 at Chandanbati with an average of 25.22 (Table 2).
Fig. 6 Wilcox Diagram showing groundwater classification based on \% Na and EC

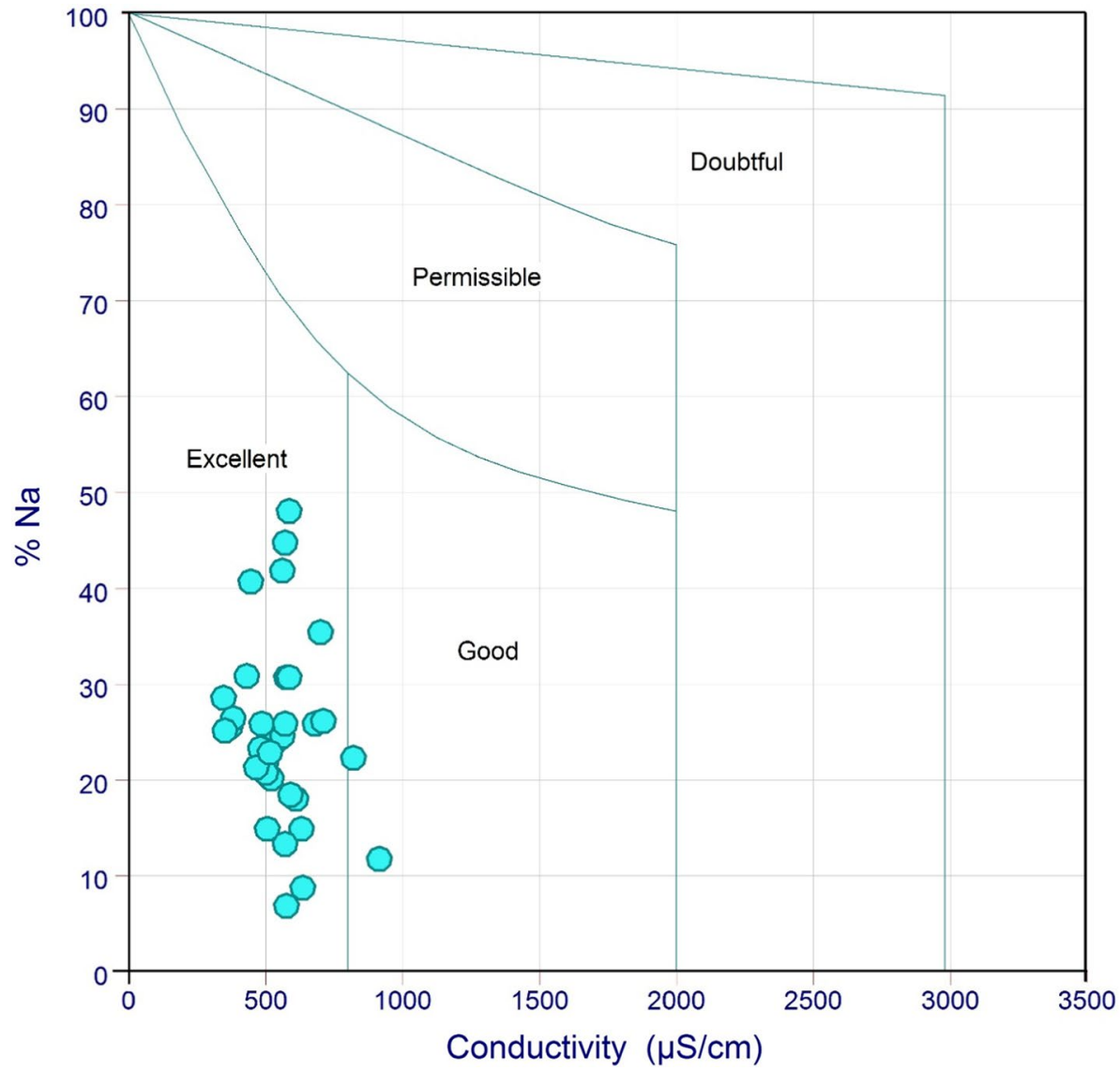




\section{Permeability index (PI)}

The content of $\mathrm{Na}^{+}, \mathrm{Mg}^{2+}, \mathrm{Ca}^{2+}$ and $\mathrm{HCO}_{3}{ }^{-}$induces soil permeability, which affects the consistency of irrigation water over time. Depending on the permeability index (PI), Doneen (1964) classified the irrigation water into three groups; Class- I, Class - II and Class- III. Class I and II are suitable and moderately suitable for irrigation purpose and Class III is unsuitable for irrigation. Based upon the PI values of the groundwater samples from Sagardighi, only $3 \%$ of the samples are Class I type and are perfectly suitable for irrigation purpose. About $88 \%$ of the samples are of Class II type, moderately appropriate and $9 \%$ of them are of Class III type and are not suitable for irrigation purposes.

\section{Multivariate statistical analysis}

Multivariate statistical analysis, such as hierarchical cluster analysis (HCA) and principal component analysis (PCA), can better explain the correlation between a large numbers of variables in groundwater research (Singh et al. 2011; Nosrati and Van Den Eeckhaut 2012; Helena et al. 2000; Chai et al. 2020). In the present study, 33 groundwater samples were classified into 3 subgroups and 2 groups and plotted in

\section{Labe 1}

\section{$C$ i S E}

Karaiya
Harahari
Sitalpara
Meghasihara
Chandanbati
Gangadda
Frezarnagar
Jugor
Diara
Gobardhan danga
Ekrakhi
Chamurgram
Kherur
Pilki
Naopara
Fulban
Poradanga
Baneswar
Bajitpur
Chandigram
Binodbati
Sagardihi
Manigram
Gayespur
Belaipara
Dumaipur
Malidanga
Choapukuria
Chandpara
Dangapara
Gauripur
Fulbari
Gosaingram

Rescaled Distance Cluster Combine
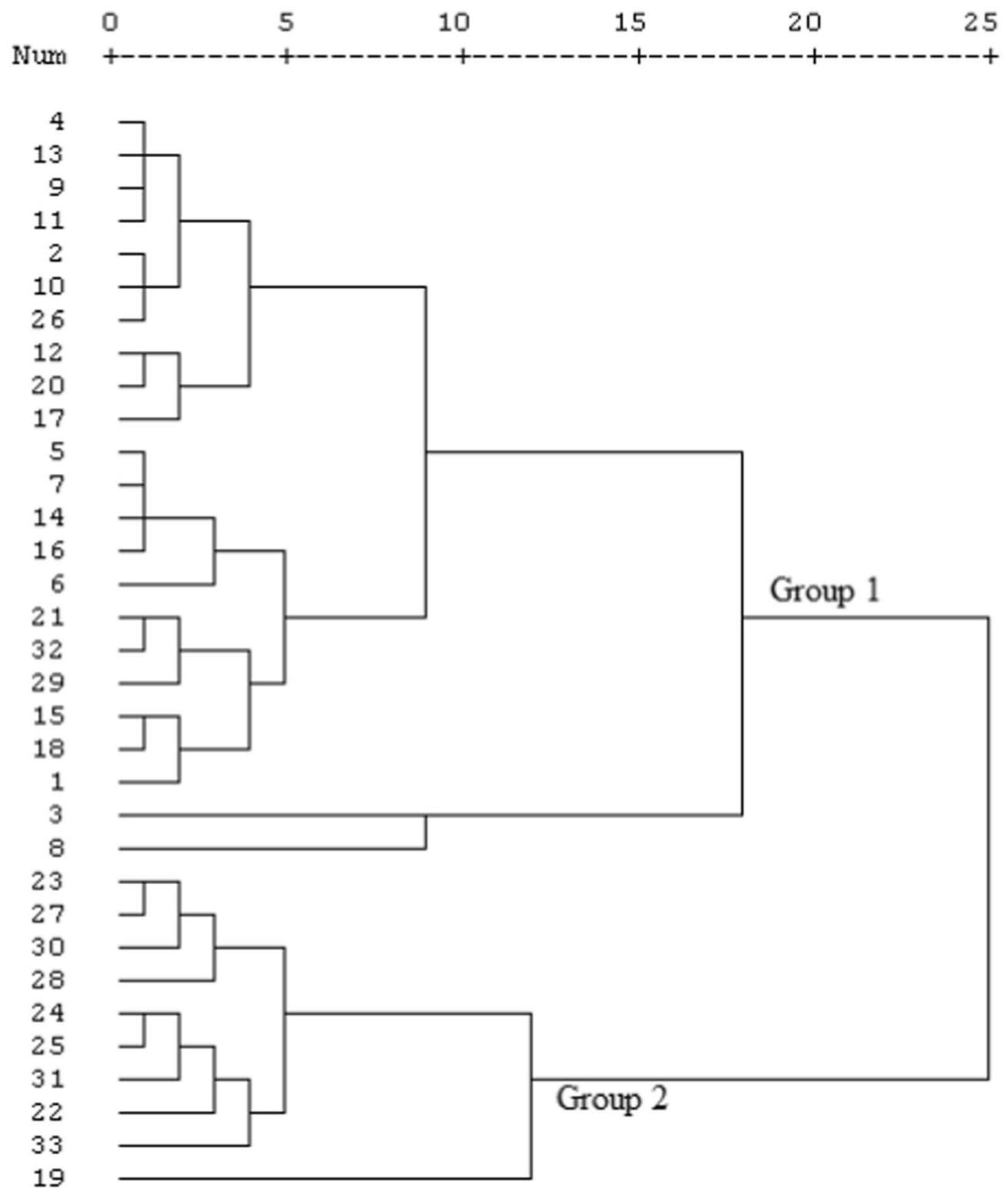

Fig. 7 Dendrogram showing cluster of variables (HCA) 
dendrogram by using HCA analysis (Fig. 7). Average linkage (between groups) was used for clustering among the samples, and squared Euclidean distance method was used for measuring distance of linkage. A large number of samples are clustered in first group. In this group, very close

Table 4 Varimax rotated factor loading and eigenvalues of principal components

\begin{tabular}{lccl}
\hline Variable & Factor 1 & Factor 2 & Factor 3 \\
\hline SAR & $\mathbf{0 . 9 7}$ & 0.01 & -0.06 \\
KR & $\mathbf{0 . 9 7}$ & 0.19 & 0.08 \\
$\mathrm{Na} \%$ & $\mathbf{0 . 9 4}$ & 0.31 & 0.06 \\
$\mathrm{RSC}$ & 0.16 & $\mathbf{0 . 9 1}$ & 0.10 \\
$\mathrm{TH}$ & -0.29 & -0.78 & -0.30 \\
$\mathrm{Cl}^{-}$ & -0.01 & -0.78 & 0.42 \\
$\mathrm{PI}$ & 0.54 & 0.65 & 0.23 \\
$\mathrm{pH}$ & -0.09 & -0.02 & -0.88 \\
EC & 0.03 & -0.08 & $\mathbf{0 . 8 5}$ \\
MAR & -0.03 & 0.23 & 0.38 \\
Eigen value & 4.23 & 1.93 & 1.66 \\
$\%$ variance & 42.33 & 19.25 & 16.58 \\
Cumulative \% variance & 42.33 & 61.57 & 78.16 \\
\hline
\end{tabular}

Bold values indicate strong $(>0.75)$ loading similarity has found among sample number $2,4,9,10,11$, $12,13,17,20$ and 26 (subgroup 1). Another close similarity has been found among sample number $1,3,5,6,7,8,14.15$, 16, 18, 21, 29 and 32 (subgroup 2). Group 1 comprise with high values of $\mathrm{pH}, \mathrm{TH}$ and SAR. In dendrogram, second group is showing strong similarity of water quality among sample number 19, 22, 23, 24, 25, 27, 28, 30, 31 and 33 (subgroup 3). Second group comprise with high values of $\mathrm{Cl}^{-}, \mathrm{EC}, \mathrm{RSC}$ and PI in irrigational groundwater.

PCA shows the relationship between variables by minimizing the data structure's complexity. It incorporates the transformation of the original variables into new uncorrelated variables known as principle components, which is performed by diagonalizing the data structure's correlation matrix. (Helena et al. 2000; Chapagain et al. 2010). In the present study, PCA was performed by varimax rotation and Kaiser normalisation. The varimax rotation of factor loadings is shown in Table 4. Eigen values of 3 factors have been found greater than 1 in the PCA, which were rotated in 5 iterations. Factor 1 with $42.33 \%$ of the total variance shows high positive loadings of SAR, KR and sodium percentage to the groundwater and very low contribution of $\mathrm{Cl}^{-}, \mathrm{TH}$, MAR and pH. Factor 2 with $19.25 \%$ of total variance indicates high positive loadings of RSC, PI, $\mathrm{Na} \%$ and negative loading of $\mathrm{TH}, \mathrm{Cl}^{-}, \mathrm{pH}$, and EC. Factor 3 of $16.58 \%$ total

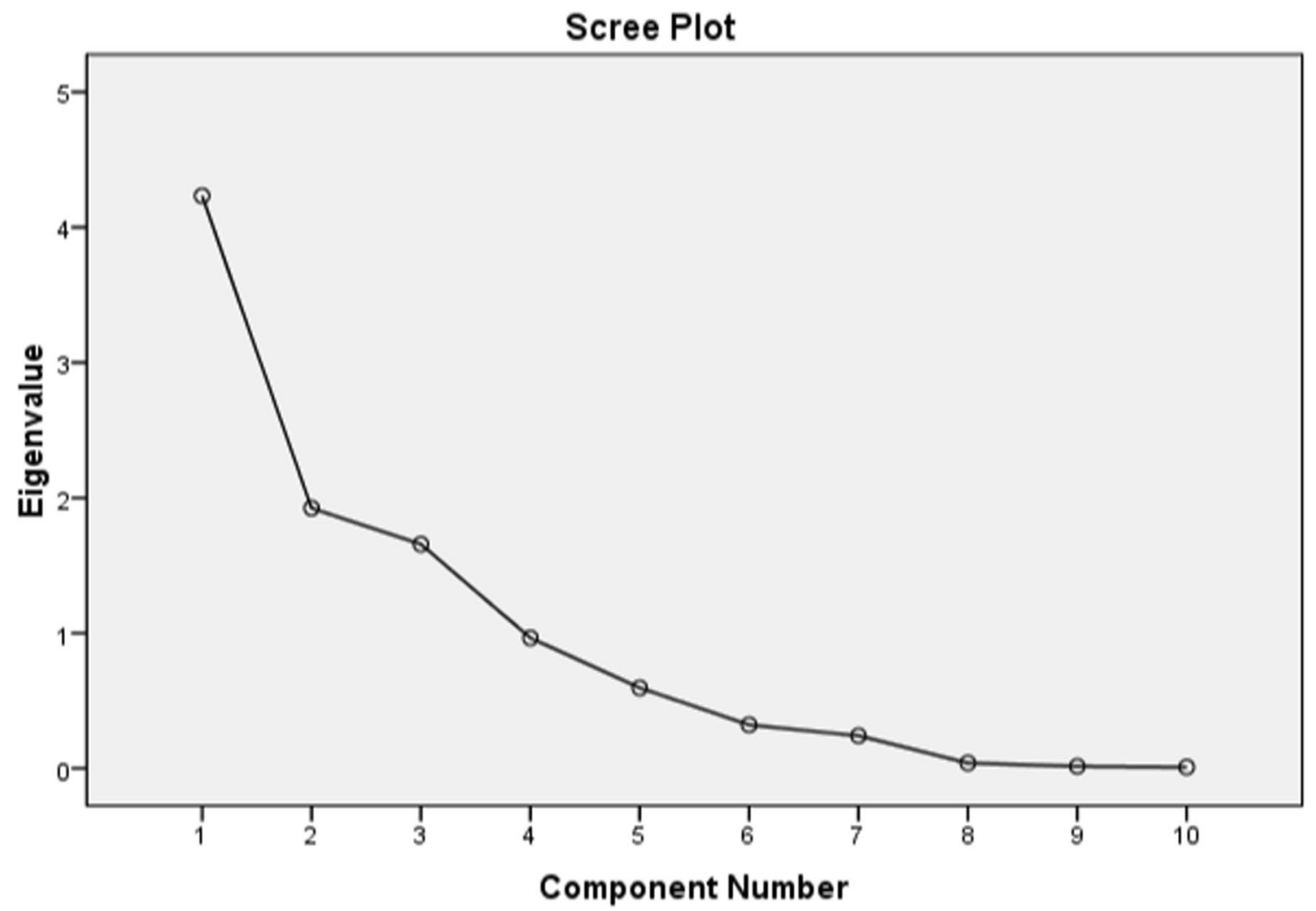

Fig. 8 Scree plot of eigen values of PCA 
Table 5 Correlation analysis of irrigational groundwater quality parameters

\begin{tabular}{lrrrrrrrrrl}
\hline Parameters & \multicolumn{1}{l}{$\mathrm{Cl}^{-}$} & \multicolumn{1}{l}{$\mathrm{EC}$} & $\mathrm{pH}$ & $\mathrm{TH}$ & $\mathrm{SAR}$ & $\mathrm{Na} \%$ & $\mathrm{MAR}$ & $\mathrm{RSC}$ & $\mathrm{KR}$ & $\mathrm{PI}$ \\
\hline $\mathrm{Cl}^{-}$ & 1.00 & & & & & & & & \\
$\mathrm{EC}$ & 0.35 & 1.00 & & & & & & & & \\
$\mathrm{pH}$ & -0.25 & -0.64 & 1.00 & & & & & & & \\
$\mathrm{TH}$ & 0.39 & -0.17 & 0.26 & 1.00 & & & & & & \\
$\mathrm{SAR}$ & -0.13 & 0.00 & -0.08 & -0.21 & 1.00 & & & & & \\
$\mathrm{Na} \%$ & -0.22 & 0.02 & -0.15 & -0.55 & $\mathbf{0 . 9 1}$ & 1.00 & & & & \\
MAR & -0.06 & 0.05 & -0.33 & -0.17 & 0.01 & 0.12 & 1.00 & & & \\
RSC & -0.69 & 0.09 & -0.14 & -0.68 & 0.19 & 0.41 & 0.09 & 1.00 & & \\
KR & -0.16 & 0.09 & -0.18 & -0.45 & $\mathbf{0 . 9 5}$ & $\mathbf{0 . 9 7}$ & 0.06 & 0.34 & 1.00 & \\
PI & -0.22 & 0.14 & -0.13 & -0.76 & 0.44 & $\mathbf{0 . 7 1}$ & 0.16 & $\mathbf{0 . 7 0}$ & $\mathbf{0 . 6 1}$ & 1.00 \\
\hline
\end{tabular}

Bold values indicate correlation greater than $0.50 \%$ variance indicates high positive loadings of EC, MAR and $\mathrm{Cl}$ and negative loading of $\mathrm{pH}$ and $\mathrm{TH}$ in the groundwater. Scree plot is shown in Fig. 8.

Correlation matrix (Table 5) was used to demonstrate the interrelationship between the analysed parameters to identify their sources of origin. Correlation analysis is a powerful tool of statistics which explains the interrelation between two parameters and indicates the dependency of each parameter to others to control water quality (Belkhiri and Narany 2015; Chakraborty et al. 2021). Correlation coefficient result shows that there was a moderately positive correlation between KR and PI $(r=0.61)$. SAR is also highly related with sodium percentage $(r=0.91)$ and $\mathrm{KR}$ $(r=0.95)$. Sodium percentage is highly correlated with $\mathrm{KR}$ $(r=0.97)$ and PI $(r=0.71)$. RSC is moderately correlated with PI $(r=0.70)$.

\section{Conclusion}

In this study, $12 \%$ of the groundwater samples (Karaiya, Jugor, Gobardhan danga, Diara) have EC values less than $250 \mu \mathrm{S} / \mathrm{cm}$ and are excellent for irrigation, while $88 \%$ of the groundwater samples have EC values ranging from 250-750 $\mu \mathrm{S} / \mathrm{cm}$ and are therefore good for irrigation with no such salinity hazard. Here, the concentration of carbonate in the water samples is negligible. The SAR value of majority of the water samples in the study area are less than 10 and are therefore excellent for irrigation purpose while a few are only fairly suitable. The highest chloride concentration $(163.1 \mathrm{mg} / \mathrm{l})$ has been reported from Sagardighi, while the lowest has been found in Belaipara (7.1 mg/l). The Kelly's ratio ranges from 0.095 to 1.083 with an average value of 1.15. Majority of the groundwater samples show a very high iron content. The PI of the groundwater samples indicate that they are moderately suitable for irrigation purpose. The sodium percentage values in the study area range from 9.47 to $55.01 \%$ with an average value of $31 \%$. The USSL plot shows that majority of the samples fall in the S1C2 and $\mathrm{S} 2 \mathrm{C} 1$ zone which means very low sodium hazard and moderate salinity hazard indicating suitability for agricultural purpose. Correlation analysis shows that sodium adsorption ratio, sodium percentage and permeability index are most dominant parameter. Principal component analysis also indicates that sodium adsorption ratio, sodium percentage and Kelly's ratio are the principal factors of controlling irrigation water quality. Hierarchical cluster analysis presents two groups of water samples. This present study also suggests that the groundwater having moderate suitability can be utilized for irrigating and cultivation crops which are somewhat tolerant to salt. In the near future, the study's output findings will help policymakers in making decisions about crop production, groundwater resource management, and sustainable design.

Acknowledgements The authors are grateful to the State Water Investigation Directorate (SWID), Kolkata and Agro-irrigation officers, Murshidabad for providing hydrogeological information related to the Sagardighi block. The authors also extend their thanks to anonymous Reviewers for their valuable constructive comments and suggestion

Authors' contributions Conceptualization: BPM, AC, AB; Data curation: BPM, RS, AC; Formal analysis and investigation; AC. AB, BPM; Writing- original draft preparation: $\mathrm{AB}, \mathrm{AC}$; Writing-review and editing: BPM, AC, AB; Supervision: BPM, RS. All authors read and approved the final manuscript.

Funding The authors received no specific funding for this work.

Availability of data and materials The datasets used and/or analysed during the current study are available from the corresponding author on reasonable request.

\section{Declarations}

Conflict of interest The authors declare that there is no conflict of interest, and they have no known competing financial interests or personal relationships that could have appeared to influence the work reported in this paper. 
Open Access This article is licensed under a Creative Commons Attribution 4.0 International License, which permits use, sharing, adaptation, distribution and reproduction in any medium or format, as long as you give appropriate credit to the original author(s) and the source, provide a link to the Creative Commons licence, and indicate if changes were made. The images or other third party material in this article are included in the article's Creative Commons licence, unless indicated otherwise in a credit line to the material. If material is not included in the article's Creative Commons licence and your intended use is not permitted by statutory regulation or exceeds the permitted use, you will need to obtain permission directly from the copyright holder. To view a copy of this licence, visit http://creativecommons.org/licenses/by/4.0/.

\section{References}

Adimalla N (2020) Controlling factors and mechanism of groundwater quality variation in semiarid region of South India: an approach of water quality index (WQI) and health risk assessment (HRA). Environ Geochem Health 42:1725-1752. https:// doi.org/10.1007/s10653-019-00374-8

Anand B, Karunanidhi D, Subramani T, Srinivasamoorthy K, Suresh M (2019) Long-term trend detection and spatiotemporal analysis of groundwater levels using GIS techniques in lower Bhavani River basin, Tamil Nadu, India. Environ Dev Sustain 22:27792800. https://doi.org/10.1007/s10668-019-00318-3

Aouiti S, Azaza FH, El Melki F, Hamdi M, Celico F, Zammouri M (2020) Groundwater quality assessment for different uses using various water quality indices in semi-arid region of central Tunisia. Environ Sci Pollut Res 28:1-23. https://doi.org/10. 1007/s11356-020-11149-5

APHA (1998) Standard methods for the examination of water and waste water, 20th edn. American Public Health Association, Washington

Aravinthasamy P, Karunanidhi D, Subramani T, Roy PD (2021) Demarcation of groundwater quality domains using GIS for best agricultural practices in the drought-prone Shanmuganadhi River basin of South India. Environ Sci Pollut Res 28(15):18423-18435. https://doi.org/10.1007/ s11356-020-08518-5

Asante-Annor A, Bewil PN, Boateng D (2018) Evaluation of groundwater suitability for irrigation in the Lambussie-Karni District of Ghana. Ghana Min J 18(1):9-19. https://doi.org/10.4314/gm/ v18i1.2

Ayers RS, Westcot DW (1985) Water quality for agriculture. FAO irrigation and drainage paper $29 \mathrm{rev} 1$. Food and agriculture organization of the United Nations, Rome, Italy, p 174

Bauder TA, Waskom R, Sutherland P, Davis J, Follett R, Soltanpour P (2011) Irrigation water quality criteria service in action; no 0506

Bera A, Das S (2021) Water resource management in semi-arid Purulia District of West Bengal, in the context of sustainable development goals. In: Shit PK, Bhunia GS, Adhikary PP, Dash CJ (eds) Groundwater and society. Springer, Cham. Doi: https:// doi.org/10.1007/978-3-030-64136-8_23

Belkhiri L, Narany TS (2015) Using multivariate statistical analysis, geostatistical techniques and structural equation modeling to identify spatial variability of groundwater quality. Water Resour Manage 29:2073-2089. https://doi.org/10.1007/s11269-015-0929-7

Bera A, Mukhopadhyay BP, Barua S (2020) Delineation of groundwater potential zones in Karha river basin, Maharashtra, India, using AHP and geospatial techniques. Arab J Geosci 13(15):121. https://doi.org/10.1007/s12517-020-05702-2

Bera A, Mukhopadhyay BP, Chowdhury P, Ghosh A, Biswas S (2021) Groundwater vulnerability assessment using GIS-based DRASTIC model in Nangasai River Basin, India with special emphasis on agricultural contamination. Ecotoxicol Environ Saf 214:112085. https://doi.org/10.1016/j.ecoenv.2021.112085

Bernstein L (1975) Effects of salinity and sodicity on plant growth. Annu Rev Phytopathol 13(1):295-312

Biswas S, Mukhopadhyay BP, Bera A (2020) Delineating groundwater potential zones of agriculture dominated landscapes using GIS based AHP techniques: a case study from Uttar Dinajpur district. West Bengal Environ Earth Sci 79(12):1-25. https:// doi.org/10.1007/s12665-020-09053-9

CGWB (2020) Aquifer mapping and management of ground water resources: parts of Murshidabad district ( 9 blocks), Farakka, Samserganj, Suti II, Suti I, Raghunathganj I, Sagardighi, Nabagram, Khargram and Kandi. Central Ground Water Board, eastern region, Kolkata.

Chai Y, Xiao C, Li M, Liang X (2020) Hydrogeochemical characteristics and groundwater quality evaluation based on multivariate statistical analysis. Water 12(10):2792. https://doi.org/10.3390/ w12102792

Chakraborty B, Roy S, Bera A, Adhikary PP, Bera B, Sengupta D, Bhunia GS, Shit PK (2021) Geospatial assessment of groundwater quality for drinking through water quality index and human health risk index in an upland area of Chota Nagpur Plateau of West Bengal, India. In: Spatial modeling and assessment of environmental contaminants (pp 327-358). Springer, Cham. Doi: https://doi.org/ 10.1007/978-3-030-63422-3_19

Chapagain SK, Pandey VP, Shrestha S, Nakamura T, Kazama F (2010) Assessment of deep groundwater quality in Kathmandu Valley using multivariate statistical techniques. Water Air Soil Pollut 210:277-288. https://doi.org/10.1007/s11270-009-0249-8

Chatterjee R, Samadder S, Mondal D, Adhikari K (2020) Analysis of spatio-temporal trend in groundwater elevation data from arsenic affected alluvial aquifers-Case study from Murshidabad district, West Bengal. Eastern India J Earth Syst Sci 129:228. https://doi. org/10.1007/s12040-020-01489-8

Chowdhury M, Paul PK (2019) Quantification of groundwater resource of Kandi subdivision of Murshidabad district, West Bengal. Environ Dev Sustain 22:5849-5871. https://doi.org/10.1007/ s10668-019-00454-w

Doneen LD (1964) Notes on water quality in agriculture published as a water science and engineering paper 4001. University of California, Department of Water Science and Engineering

Durov SA (1948) Natural waters and graphic representation of their composition. In Dokl Akad Nauk SSSR 59(3):87-90

Eaton FM (1950) Significance of carbonate in irrigation water. Soil Sci 62(2):123-133

Farooq SH, Chandrasekharam D, Berner Z, Norra S, Stüben D (2010) Influence of traditional agricultural practices on mobilization of arsenic from sediments to groundwater in Bengal delta. Water Res 44(19):5575-5588. https://doi.org/10.1016/j.watres.2010.05.057

Fipps G (2003) Irrigation water quality standards and salinity management strategies. Texas Agricultural Extension Service, Texas A\&M University System, College Station, TX (USA). B-1667, 4-03, pp 1-19.

Foster SSD, Perry CJ (2010) Improving groundwater resource accounting in irrigated areas: a prerequisite for promoting sustainable use. Hydrogeol J 18(2):291-294

Grönwall J, Danert K (2020) Regarding groundwater and drinking water access through a human rights lens: self-supply as a norm. Water 12(2):419. https://doi.org/10.3390/w12020419

Hadas A, Frenkel H (1982) Infiltration as affected by long-term use of sodic-saline water for irrigation. Soil Sci Soc Am J 46(3):524 530. https://doi.org/10.2136/sssaj1982.03615995004600030016x

Helena B, Pardo R, Vega M, Barrado E, Fernandez JM, Fernandez L (2000) Temporal evolution of groundwater composition in an alluvial aquifer (Pisuerga River, Spain) by principal component 
analysis. Water Res 34(3):807-816. https://doi.org/10.1016/ S0043-1354(99)00225-0

Islam MA, Rahman MM, Bodrud-Doza M, Muhib MI, Shammi M, Zahid A, Akter Y, Kurasaki M (2018) A study of groundwater irrigation water quality in south-central Bangladesh: a geo-statistical model approach using GIS and multivariate statistics. Acta Geochimica 37(2):193-214

Kadam A, Wagh V, Patil S, Umrikar B, Sankhua R, Jacobs J (2021) Seasonal variation in groundwater quality and beneficial use for drinking, irrigation, and industrial purposes from Deccan Basaltic Region. Western India Environ Sci Pollut Res 8:1-23. https://doi. org/10.1007/s11356-020-12115-X

Kamaraj J, Sekar S, Roy PD, Senapathi V, Chung SY, Perumal M, Nath AV (2021) Groundwater pollution index (GPI) and GIS-based appraisal of groundwater quality for drinking and irrigation in coastal aquifers of Tiruchendur. South India Environ Sci Pollut Res 2:1-19. https://doi.org/10.1007/s11356-021-12702-6

Karunanidhi D, Vennila G, Suresh M, Subramanian SK (2013) Evaluation of the groundwater quality feasibility zones for irrigational purposes through GIS in Omalur Taluk, Salem District. South India Environ Sci Pollut Res 20(10):7320-7333. https://doi.org/ 10.1007/s11356-013-1746-2

Keesari T, Ramakumar KL, Chidambaram S, Pethperumal S (2016) Understanding the hydrochemical behaviour of groundwater and its suitability for drinking and agricultural purposes in Pondicherry area, South India-a step towards sustainable development. Groundw Sustain Dev 2-3:143-215. https://doi.org/10.1016/j.gsd. 2016.08.001

Kelley WP (1940) Permissible composition and concentration of irrigated waters. Proc ASCF 66:607

Kumar B, Gangwar V, Parihar SKS (2017) Effect of saline water irrigation on germination and yield of wheat (Triticum aestivum L.) genotypes. Agrotechnology 6(1):156.

Kundu A, Nag SK (2018) Assessment of groundwater quality in Kashipur Block, Purulia district. West Bengal Appl Water Sci 8(1):33. https://doi.org/10.1007/s13201-018-0675-0

Little J, Kalischuk A, Gross D, Sheedy C (2010) Assessment of water quality in Alberta's irrigation districts. Alberta Agriculture and Rural Development, Alberta.

Malash N, Ghaibeh A, Yeo A, Ragab R, Cuartero J (2000) Effect of irrigation water salinity on yield and fruit quality of tomato. In International Symposium on Techniques to Control Salination for Horticultural Productivity 573 (pp. 415-423).

Margat J, Van der Gun J (2013) Groundwater around the world. CRC Press/ Balkema, Leiden

Mohr F (1862) Lehrbuch der chemisch-analytischen Titrirmethode. F. Vieweg und Sohn

Mukherjee A, Fryar AE, Rowe HD (2007) Regional-scale stable isotopic signatures of recharge and deep groundwater in the arsenic affected areas of West Bengal, India. J Hydrol 334:151-161. https://doi.org/10.1016/j.jhydrol.2006.10.004

Mukhopadhyay BP, Barua S, Bera A, Mitra AK (2020) Study on the quality of groundwater and its impact on human health: a case study from Murshidabad District, West Bengal. J Geol Soc India 96:597-602. https://doi.org/10.1007/s12594-020-1608-8

Naseem S, Hamza S, Bashir E (2010) Groundwater geochemistry of Winder agricultural farms, Balochistan, Pakistan and assessment for irrigation water quality. Eur Water 31:21-32

Nosrati K, Van Den Eeckhaut M (2012) Assessment of groundwater quality using multivariate statistical techniques in Hashtgerd Plain. Iran Environ Earth Sci 65:331-344. https://doi.org/10.1007/ s12665-011-1092-y

Nouri H, Borujeni SC, Nirola R, Hassanli A, Beecham S, Alaghmand S, Saint C, Mulcahy D (2017) Application of green remediation on soil salinity treatment: a review on halophytoremediation.
Process Saf Environ Prot 107:94-107. https://doi.org/10.1016/j. psep.2017.01.021

Piper AM (1944) A graphic procedure in the geochemical interpretation of water-analyses. Eos Trans AGU 25(6):914-928. https:// doi.org/10.1029/TR025i006p00914

Rabeiy RE (2018) Assessment and modeling of groundwater quality using WQI and GIS in Upper Egypt area. Environ Sci Pollut Res 25(31):30808-30817. https://doi.org/10.1007/s11356-017-8617-1

Rao NS, Dinakar A, Sravanthi M, Kumari BK (2021) Geochemical characteristics and quality of groundwater evaluation for drinking, irrigation, and industrial purposes from a part of hard rock aquifer of South India. Environ Sci Pollut Res 8:1-21. https://doi.org/10. 1007/s11356-021-12404-z

Rhoades JD (1987) Use of saline water for irrigation. Water Quality Bull 12:14-20

Richards LA (1954) Diagnosis and improvement of saline and alkali soils (Vol. 78, No. 2, p. 154). LWW.

Romanelli A, Lima ML, Londono OMQ, Martínez DE, Massone HE (2012) A GIS-based assessment of groundwater suitability for irrigation purposes in flat areas of the Wet Pampa Plain, Argentina. Environ Manage 50:490-503. https://doi.org/10.1007/ s00267-012-9891-9

Saleh A, Al-Ruwaih F, Shehata M (1999) Hydrogeochemical processes operating within the main aquifers of Kuwait. J Arid Environ 42:195-209. https://doi.org/10.1006/jare.1999.0511

Sawyer CN, McCarty PL (1967) Chemistry for sanitary engineers, 2nd edn. McGraw Hill, New York, p 518

Şener Ş, Varol S, Şener E (2021) Evaluation of sustainable groundwater utilization using index methods (WQI and IWQI), multivariate analysis, and GIS: the case of Akşehir District (Konya/ Turkey). Environ Sci Pollut Res 9:1-20. https://doi.org/10.1007/ s11356-021-14106-y

Simsek C, Gunduz O (2007) IWQ index: a GIS-integrated technique to assess irrigation water quality. Environ Monit Assess 128:277300. https://doi.org/10.1007/s10661-006-9312-8

Singh CK, Shashtri S, Mukherjee S (2011) Integrating multivariate statistical analysis with GIS for geochemical assessment of groundwater quality in Shiwaliks of Punjab, India. Environ Earth Sci 62:1387-1405. https://doi.org/10.1007/s12665-010-0625-0

Struik PC, Kuyper TW (2017) Sustainable intensification in agriculture: the richer shade of green. A review. Agron Sustain Dev 37(5). https://doi.org/10.1007/s13593-017-0445-7

Subba Rao N (2002) Geochemistry of groundwater in parts of Guntur District, Andhra Pradesh, India. Environ Geol 41:552-562. https://doi.org/10.1007/s002540100431

Subramani T, Elango L, Damodarasamy SR (2005) Ground water quality and suitability for drinking and agricultural in chithar river basin, Tamilnadu, India. Environ Geol 47:1099-1110. https://doi. org/10.1007/s00254-005-1243-0

Sundaray SK, Nayak BB, Bhatta D (2009) Environmental studies on river water quality with reference to suitability for agricultural purposes: Mahanadi river estuarine system, India-a case study. Environ Monit Assess 155:227-243. https://doi.org/10.1007/ s10661-008-0431-2

Szabolcs I, Darab C (1964) The influence of irrigation water of high sodium carbonate content of soils. In Proceedings of the 8th international congress of ISSS, Tsukuba, Japan. pp 803-812

Tucker BB, Kurtz LT (1961) Calcium and magnesium determinations by EDTA titrations. Soil Sci Soc Am J 25(1):27-29. https://doi. org/10.2136/sssaj1961.03615995002500010016x

UNESCO (2012) World's groundwater resources are suffering from poor governance. UNESCO Publishing, Paris, France

Verma P, Singh PK, Sinha RR, Tiwari AK (2020) Assessment of groundwater quality status by using water quality index (WQI) and geographic information system (GIS) approaches: a case 
study of the Bokaro district, India. Appl Water Sci 10:27(1-16). Doi: https://doi.org/10.1007/s13201-019-1088-4

Wang S (2013) Groundwater quality and its suitability for drinking and agricultural use in the Yanqi Basin of Xinjiang Province, Northwest China. Environ Monit Assess 185:7469-7484. https://doi. org/10.1007/s10661-013-3113-7

WHO (1989) Guidelines for the safe use of wastewater and excreta in agriculture and aquaculture: World Health Organization. 187

WHO (2011) Guidelines for drinking-686 water quality, Edition. F Chronicle 38(4):104-108
Wilcox LV (1955) Classification and use of irrigation waters (No. 969). US Department of Agriculture, Washington.

Publisher's Note Springer Nature remains neutral with regard to jurisdictional claims in published maps and institutional affiliations. 